UDC 343.985:349.412.2

DOI: $10.31733 / 2078-3566-2019-5-224-228$

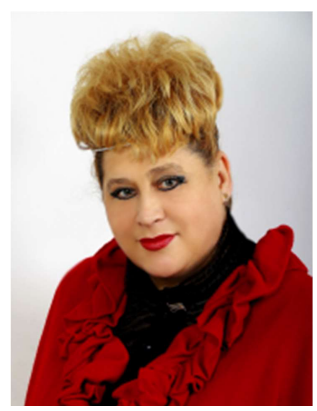

Inna YEFIMOVA ${ }^{\oplus}$

Ph.D

(University of Customs and Finance, Dnipro)

\title{
ORGANIZATIONAL FEATURES OF OPERATING AND SEARCHING SECURITY OF WORKERS OF CUSTOMS OF UKRAINE
}

ІнНа Єфімова. ОРГАНІЗАЦІЙНІ ОСОБЛИВОСТІ ОПЕРАТИВНО-РОЗШУКОВОГО ЗАБЕЗПЕЧЕННЯ БЕЗПЕКИ ПРАЦІВНИКІВ МИТНИЦІ УКРАЇНИ. ДослідЖеНО організаційні особливості оперативно-розшукового забезпечення безпеки працівників митниці України. Акцентується увага на висвітлені теоретично сформульованих та емпірично доведених положень i рекомендацій щодо оперативно-розшукового забезпечення безпеки працівників митниці та запропоновано шляхи удосконалення цієї діяльності з урахуванням реформування оперативно-розшукового законодавства та безпосередньо положень нового Кримінального процесуального кодексу України.

Підкреслюється, що визнаючи значимість здобутків науковців, оперативно-розшукове забезпечення безпеки працівників митниці й досі залишається актуальним. Можливо публічне обговорення зазначених проблем підвищить ефективність оперативно-розшукової практики забезпечення безпеки не тільки працівників митниці, а й інших правоохоронних органів України у контексті глобального реформування законодавства України.

Наголошено, що велике значення для правового регулювання оперативно-розшукового забезпечення безпеки працівників митниці України при виконанні службово-професійних завдань мають закони України «Про державний захист працівників суду і правоохоронних органів» та «Про забезпечення безпеки осіб, які беруть участь у кримінальному судочинстві», якими передбачено систему заходів від перешкоджання виконанню покладених обов'язків і здійсненню наданих прав, а так само від посягань на життя, здоров'я, житло і майно зазначених осіб та їх близьких родичів у зв'язку зі службовою діяльністю.

Вказано, що комплекс правових заходів, у першу оперативно-розшукових, повинен гарантувати співробітникам та їх близьким родичам їх правовий, фізичний, психологічний захист та захист немайнових прав і свобод у разі виникнення необхідності. Але багато проблем виникає під час реалізації заходів безпеки. Насамперед не відпрацьовано механізм реалізації цих заходів, швидкість та оперативність проведення відповідних заходів, відсутнє належне матеріальнотехнічне забезпечення їх реалізації (наприклад, необхідно швидко зробити операцію зі зміни зовнішності співробітника тощо). Для більш ефективної реалізації заходів, передбачених цими законами, необхідно ввести до структури Державної фіскальної служби України спеціальний підрозділ, на який буде покладено вирішення заходів безпеки або який штатно можна ввести в управління власної безпеки працівників органів Державної фіскальної служби України.

Ключові слова: оперативно-розщукова діяльність, негласні слідчі (розщукові) дії, оперативно-розшукове забезпечення, безпека, працівники митниці, підрозділи власної безпеки, Державна фіскальна служби України.

Problem statement. The formation of a new socio-economic structure of Ukraine, the formation and transformation of state institutions are fraught with many problems. Objective complexity and subjective miscalculations in the course of large-scale reforms have determined the intensification of criminal processes and the transformation of criminal activity into a social practice, which acquires new systemic quality due to the active establishment of corrupt relationships and the penetration of power structures.

The legal status of customs officers has also changed dramatically. The activity on provocations, attempts of unlawful pressure on customs officers was intensified. According to statistics, 17 crimes were registered against customs officers in 2016, 23 crimes in 2017, and 21 crimes in 2018.

Analysis of publications that stated solving this problem. The theoretical basis of the

(C) Yefimova I., 2019 
article was the work of domestic and foreign scientists in the field of theory of operative-search activity and counteracting organized crime, in particular: M.I. Anufriyev, K.V. Antonov, O.M. Bandurka, V.I. Vasylinchuk, S.M. Gusarov, O.M. Dzhuzha, E.O. Didorenko, O.F. Dolzhenkov, V.P. Zakharov, O.V. Kyrychenko, A.M. Kyslyy, I.P. Kozachenko, O.I. Kozachenko, O.E. Korystin, S.I. Minchenko, D.Yo. Nikiforchuk, V.A. Nekrasov, S.V. Slinko, S.V. Obshalov, V.L. Ortynsky, M.A. Pogoretsky, D.V. Priymachenko, V.D. Pcholkin, V.S. Sapsay, V.V. Topchiy, V.G. Teliychuk, O.V. Khusainov, S.S. Chernyavsky, O.O. Yukhno, V.V. Shendryk, I.R. Shynkarenko and others.

Recognizing the importance of the achievements of these scientists, it is necessary to emphasize that the operative-search security of the customs employees is still relevant. It is possible that public discussion of these problems will increase the effectiveness of the operative-search practice of ensuring security not only of customs officers, but also of other law enforcement agencies of Ukraine in the context of global reform of Ukrainian legislation.

The article's objective is to clarify theoretically formulated and empirically proven provisions and recommendations on the operative-search security of customs officers and to propose ways of improving this activity taking into account the reform of the operative-search legislation and directly the provisions of the new Criminal Procedure Code of Ukraine.

Basic content. In the science of the legal cycle, increasing attention is paid to the research of investigative and operational security of law enforcement officials and employees of the customs of Ukraine. Given the changes in the structure and dynamics of crime, there is a corresponding specialization of research in the analysis of operational security search of the security of law enforcement officers by the relevant categories of operational investigation cases or interaction with individual operational units of the National Police.

The laws of Ukraine "On State Protection of Court and Law Enforcement Workers" and "On Ensuring the Safety of Persons Participating in Criminal Procedure", which provide for the system, are of great importance for the legal regulation of the operational and search security of the Customs officers of Ukraine. measures to prevent the performance of assigned duties and the exercise of the rights conferred, as well as encroachment on the life, health, housing and property of these persons and their close relatives in bunch of official activities.

The complex of legal measures, in the first operational search, must guarantee the employees and their close relatives their legal, physical, psychological protection and protection of non-property rights and freedoms in case of necessity. But many problems arise when implementing security measures. First of all, the mechanism of implementation of these measures, the speed and promptness of carrying out the appropriate measures, the proper logistical support for their implementation (for example, it is necessary to make an operation to change the appearance of an employee, etc.), has not been worked out. For a more effective implementation of the measures provided for by these laws, it is necessary to introduce into the structure of the State Fiscal Service of Ukraine a special unit, which will be entrusted with the decision of security measures or which can be permanently introduced into the management of own security of employees of the State Fiscal Service of Ukraine [1].

The study of the guarantees of legal protection of the employees of the Customs of Ukraine suggests that this area does not fully meet the requirements of the time. The main reasons for this situation are the deficiencies in the structure of the State Fiscal Service of Ukraine's own security units and the declarative nature of their functions; a significant number of tasks assigned to these units; uncertainties of the peculiarities of the organization of operational and search activity of the units of own security of the State Fiscal Service of Ukraine; inadequate regulation of the activities of these units; imperfection of information-analytical work and lack of criteria for evaluation of objects of preventive (preventive) influence of the units of own safety; lack of a clear system of performance appraisal indicators; insufficient development of the system of selection of candidates for work in the internal security units of the State Fiscal Service of Ukraine on the basis of the psychological model of personality of the operative employee; the absence of an effective mechanism for the interaction of the units of their own security with the operational units of the National Police of Ukraine and other law enforcement agencies.

Analyzing the definitions of scholars, the notion of guarantees of legal protection allowed us to formulate our own interpretation. Yes, guarantees for legal protection of customs officers - is a set of basic and auxiliary measures envisaged by the Customs Code, the Criminal Procedure Code and the legislation of Ukraine on operative-search activity, aimed at reducing the level of dangerous factors to the real possible minimum, which allows to guarantee the 
preservation of life and health, normal mental state and capacity of workers Customs in the performance of functional duties, professional (operational, operational, combat) tasks in both everyday and extreme, emergency situations.

According to this definition, the main and ancillary measures of legal safeguards are considered. The main activities include: professional; spiritual; legal; tactical; psychological and pedagogical; physical; individual. Auxiliary - personnel; organizational; psychomotor; governing; medical; material and technical; social; economic.

Investigations into criminal proceedings, the opinions of scientists and practitioners have shown that, within the operational and search characteristics, the determinants that contribute to the commission of crimes against customs officers are of the greatest interest. These include objective and subjective factors of economic, political, ideological, cultural, moral and psychological, social, socio-biological, legal nature [2].

The results of the questionnaire survey of the State Fiscal Service of Ukraine's employees determined that among the types of crimes they were able to prevent or stop were crimes provided for by the Criminal Code of Ukraine: article 190 Fraud, article 342 Resistance to a Law Enforcement Officer, article 369 Offering, Promising or Misappropriating an Official ", article 370 "Provocation of bribery", article 343 of the Criminal Code of Ukraine "Interference with the activity of a law enforcement officer", article 345 "Threat or violence against a law enforcement officer", article 347 "Deliberate destruction or damage to property of a law enforcement officer", article 348 the life of a law enforcement officer, member of a public order and state border guard, or a serviceman, article 349 "Capturing a representative of a government or law enforcement officer as hostage", article 350 "Threatening or abusive behavior against an official or a public official".

Conflicts in interpersonal relationships play a significant role in committing offenses and crimes against customs officers. The encroachment and encroachment on the personality of customs officers is not only an encroachment on their fundamental rights, but also on the rights of any person, it is an encroachment on the security of the entire society.

Clashes between the two parties to the conflict may be triggered by malpractice on the part of the customs officer and the immoral behavior of the perpetrators. The specificity of customs officers' activity causes the presence of multivariate conflict situations. Authorities empowered by customs officers, the need to apply coercive measures to effectively counter criminal offenses in the customs sphere, the conditions of constant bilateral struggle, other antagonistic conditions of customs activity are the main source of any conflict situations that arise in the workplace [3].

Clashes between the two parties to the conflict may be triggered by malpractice on the part of the customs officer and the immoral behavior of the perpetrators. The specificity of customs officers' activity causes the presence of multivariate conflict situations. Authorities empowered by customs officers, the need to apply coercive measures to effectively counter criminal offenses in the customs sphere, the conditions of constant bilateral struggle, other antagonistic conditions of customs activity are the main source of any conflict situations that arise in the workplace.

The practical implementation of the model of operative-search support of criminal proceedings for crimes against customs officers is carried out under the influence of such operational-tactical situations [4].

The first situation is characterized by the fact that the operational units carry out the detection and exposition of latent and conspecific types of these crimes independently at the stage of verification in the form of operational verification or development. Documented in these organizational forms allows for the comprehensive use of the entire arsenal of covered investigative (search) actions to detect criminal signs, actual data on the tools and methods of committing acts of self-violence, objects of harm, harm to them, the behavior and actions of persons, who committed them, etc.

The second situation is typified by the mentioned crimes, which are committed under the conditions of obviousness or by methods and actions that do not make it difficult for them to be identified by the victims, eyewitnesses, others, and even more so by professional operatives and investigators of law enforcement agencies. This group of crimes consists of those committed by single or situational groups using brute force, intimidation of their victims, in places accessible to the presence and observation of others. In this situation, the adoption of operational and tactical decisions on conducting covered investigative (search) actions and the application of criminal procedural function to expose and investigate crimes against customs 
officers may be carried out solely by the individual evaluation of the material under investigation and should proceed from the objective possibility of involvement for these purposes. forces and means of the State Fiscal Service of Ukraine. Covered investigative (search) actions can and should be planned and carried out purposefully. Limited to investigative and organizational-administrative measures, this cannot be achieved.

The third situation is characterized by the disguise, suddenness and organization of criminal activities that have been left out of social control and with the highest priority of covered investigative (search) actions or provide their security with counteraction to the law enforcement function of the state. As a rule, it manifests the actions of organized crime groups that commit serious acts of self-violence ("ordered" killings, robberies against objects of customs authorities, gangster attacks on goods and motor transport of customs, hostage-taking, and the like). Covered investigative (search) actions are mainly used after serious acts of violence and violence and criminal proceedings against them, and promptly-investigating its provision creates favorable conditions for their complete and objective investigation.

Effectiveness of the system of forces, means and methods of operative-investigative activity in the operative-investigative support of criminal proceedings in cases of self-aggravated crimes against customs officers is dependent on organizational and tactical factors.

The reasons that reduce the effectiveness of the operative-search support at the stage of pre-trial investigation in criminal proceedings about self-aggrandizing crimes against customs officers are: the shortcomings of the regulatory regulation of this sphere of activity; low level of operational readiness of Ukrainian criminal police forces and means; mismatch of the level of organization of work to the requirements of time; insufficient level of professional training of operatives; the lack of modern scientific developments regarding the use of innovative technical capabilities for conducting covered investigative (search) actions.

Features of the operative-search support of the court proceedings for criminal proceedings against crimes against customs officers are the following: interaction of operative officers of the National Police with operative employees of the units of the State Fiscal Service of Ukraine's own security units and employees of the court and prosecutor's office regarding the timely detection of criminal acts; the duty of law enforcement agencies, in the face of entities of search and operative activity, to promote the practical achievement of the principle of inevitability of liability of perpetrators for committing crimes against customs officers; in addition to establishing objective truth during the trial, search and operative support is aimed at overcoming the counteraction from the criminal environment and neutralizing the criminal influence on the participants of criminal proceedings for crimes against customs officers; comprehensive use of covered forces and the entire system of operational-search methods implemented in specific activities [5].

The main directions for improving the activities of customs officers in preventing crimes against them are the following: strengthening the customs base of the customs (equipment of premises by means of video surveillance, modern means of personal protection); enrollment in the program for students of the Law Faculty of the University of Customs and Finance of the subject "Personal safety of customs officers"; enrollment in the course of initial training, retraining and advanced training of the subject "Personal security of customs officers"; development and submission to the customs authorities of practical recommendations on the application of measures of physical influence, special means and firearms in extreme situations; conducting practical seminars in the territorial divisions of customs on personal safety of workers; the introduction in the customs of the mobile groups, the so-called "customs guard", which in the event of conflict situations during the performance of duties customs officers will provide legal assistance to both customs officials and offenders.

Conclusions. Customs officers are constantly fighting crime related to smuggling and violation of customs rules throughout the customs territory of Ukraine. Their professional activities are at risk for life. In today's context, when many business entities try to circumvent the law and do not pay customs duties, using any illegal methods, customs officers face considerable opposition when countering these crimes. That is why the personal safety of customs officers is of great importance in their professional activities.

\section{References}

1. Єфімова I. В. Правове регулювання оперативно-розшукового забезпечення безпеки працівників митниці. Вісник Академії митної служби України. 2015. № 2. С. 179-184.

2. Єфімова I. В. Кримінальні процесуальні засоби забезпечення безпеки працівників митної справи України. Науковий вісник Дніпропетровського державного університету 
внутрішніх справ. 2015. № 4 (78). С. 286-291.

3. Сфімова I. В. Теоретичні проблеми оперативно-розшукового забезпечення безпеки працівників митної справи. Право і суспільство. 2015. № 6. С. 172-176.

4. Єфімова І. В. Організація і тактика оперативно-розшукового забезпечення досудового розслідування у кримінальних провадженнях по корисливо-насильницьких злочинах проти працівників митної справи України. Науковий вісник Дніпропетровського державного університету внутрішніх справ. 2015. Спец випуск № 79. С. 156-162.

5. Єфімова I. В. Особливості оперативно-розшукового забезпечення судового розгляду кримінальних проваджень по злочинах проти працівників митної справи. Вісник Харківського національного університету внутрішніх справ. 2015. Спецвипуск № 4 (71). С. 134-145.

Received to editorial office 08.12.2019

1. Yefimova, I. V. (2015) Pravove rehulyuvannya operatyvno-rozshukovoho zabezpechennya bezpeky pratsivnykiv mytnytsi [Legal regulation of operatively-search security of customs officers]. Visnyk Akademiyi mytnoyi sluzhby Ukrayiny. № 2. S. 179-184. [in Ukr.]

2. Yefimova, I. V. (2015) Kryminal'ni protsesual'ni zasoby zabezpechennya bezpeky pratsivnykiv mytnoyi spravy Ukrayiny [Criminal procedural means of ensuring the safety of the Customs officers of Ukraine]. Naukovyy visnyk Dnipropetrovs'koho derzhavnoho universytetu vnutrishnikh sprav. № 4 (78). S. 286-291. [in Ukr.]

3. Yefimova, I. V. (2015) Teoretychni problemy operatyvno-rozshukovoho zabezpechennya bezpeky pratsivnykiv mytnoyi spravy [Theoretical Problems of Operational and Investigative Security of Customs Employees]. Pravo i suspil'stvo. № 6. S. 172-176. [in Ukr.]

4. Yefimova, I. V. (2015) Orhanizatsiya i taktyka operatyvno-rozshukovoho zabezpechennya dosudovoho rozsliduvannya u kryminal'nykh provadzhennyakh po koryslyvo-nasyl'nyts'kykh zlochynakh proty pratsivnykiv mytnoyi spravy Ukrayiny [Organization and tactics of operative-search support of pretrial investigation in criminal proceedings on acts of selfish-violence and violence against customs officers of Ukraine]. Naukovyy visnyk Dnipropetrovs'koho derzhavnoho universytetu vnutrishnikh sprav. Spets vypusk № 79. S. 156-162. [in Ukr.]

5. Yefimova, I. V. (2015) Osoblyvosti operatyvno-rozshukovoho zabezpechennya sudovoho roz'hlyadu kryminal'nykh provadzhen' po zlochynakh proty pratsivnykiv mytnoyi spravy [Features of operative-search support of court proceedings of criminal proceedings on crimes against customs officers]. Visnyk Kharkivs'koho natsional'noho universytetu vnutrishnikh sprav. Spetsvypusk № 4 (71). S. 134-145. [in Ukr.]

\section{Summary}

The organizational features of operational and search security of the customs officers of Ukraine are investigated in the article. Attention is drawn to the coverage of theoretically formulated and empirically proven provisions and recommendations on the operational and investigative security of customs officers and suggests ways to improve this activity in the light of reforming the operative and investigative legislation and directly the provisions of the new Criminal Procedure Code of Ukraine.

Keywords: operational-search activity, covered investigative (search) actions, operative-search support, security, customs officers, units of their own security, State Fiscal Service of Ukraine. 